\title{
ANALÝZA ZMIEN PRIEMERNÝCH MESAČNÝCH PRIETOKOV DO ROKU 2100 NA VYBRANÝCH POVODIACH SLOVENSKA
}

\author{
ANALYSIS OF CHANGES IN AVERAGE MONTHLY DISCHARGED \\ UNTIL 2100 IN SELECTED RIVER BASINS OF SLOVAKIA
}

\author{
Zuzana Sabová*,, Silvia Kohnová ${ }^{1}$ \\ "zuzana.sabova@stuba.sk \\ ${ }^{1}$ Slovenská technická univerzita v Bratislave, Radlinského 11, 81107 Bratislava, Slovensko
}

\begin{abstract}
Abstrakt
Príspevok sa zaoberá analýzami zmien priemerných mesačných prietokov využitím klimatických scenárov MPI a KNMI vo vodomernej stanici Liptovský Mikuláš (5550) v povodí rieky Váh a vodomernej stanici Chmelnica (8320) v povodí rieky Poprad. Na dosiahnutie výsledkov sa použil program The Indicators of Hydrologic Alteration (IHA). K dispozícií boli pozorované dáta, modelované dáta pomocou modelu HBV a dáta klimatických scenárov MPI a KNMI, ktoré boli použité na modelovanie denných prietokov pomocou HBV modelu do roku 2100. Dostupné dáta boli rozdelené do štyroch časových periód: 1981-2010, 2011-2040, 2041-2070 a 2071-2100. Výsledky poukázali na znižovanie priemerných mesačných prietokov v letných mesiacoch a ich zvyšovanie v zimných mesiacoch do roku 2100.
\end{abstract}

\section{Kl'účová slová}

priemerné mesačné prietoky, klimatická zmena, klimatický scenár MPI, klimatický scenár KNMI

\begin{abstract}
The paper is focused on the analysis of changes in average monthly discharges using MPI and KNMI climate scenario in the gauging station Liptovský Mikulás (5550) in the Váh River Basin and in the gauging station Chmelnica (8320) in the Poprad River Basin. To achieve the results, the program Indicators of Hydrologic Alteration was used. Available data were, i.e., the observed daily discharge data, the modelled data from the rainfall-runoff HBV model, and the MPI and KNMI climate scenarios data were used to model daily discharges using the HBV model until 2100. Data were divided into four time periods, i.e., 1981-2010, 2011-2040, 20412070, and 2071-2100. The results showed a decrease in average monthly discharges in the summer months and an increase in the winter months until 2100.
\end{abstract}

\section{Key words}

average monthly discharges, climate change, MPI climate scenario, KNMI climate scenario

\section{1 ÚVOD}

Ciel'om príspevku je vyhodnotenie analýz priemerných mesačných prietokov vo vybraných vodomerných staniciach Váh - Liptovský Mikuláš (5550) a Poprad - Chmelnica (8320) do roku 2100 pomocou klimatických scenárov MPI a KNMI pomocou programu Indicators of Hydrologic Alteration. Na analýzy sa použili pozorované dáta, dáta modelované HBV modelom a simulované dáta klimatických scenárov MPI a KNMI pomocou HBV modelu.

Skúmaná problematika je dôležitá na preukázanie budúcich zmien v hydrologickom režime riek. Pomocou programu IHA je možné vykonat' vel'ký počet analýz, ktoré svojimi výsledkami sú možné predpokladat' extrémne javy alebo vytvorit' historické štatistiky (vel'ké povodne, extrémne nizke prietoky apod.). Je potreba, aby sa zvyšoval počet vykonaných podobných analýz, aby boli dostatočne vytvorené opatrenia na ochranu ekosystémov. 


\section{LITERÁRNY PREHLAD/POPIS SÚČASNÉHO STAVU}

Klimatická zmena má vplyv do budúcnosti na zvyšovanie priemernej teploty vzduchu a oceánov, rozsiahleho topenia snehu a l’adu, čo zapríčiňuje stúpanie hladiny morí a oceánov [1]. Extrémne hydrologické javy (najmä záplavy a obdobia sucha) sú jedny z príčin prírodných katastrof. Klimatická zmena urýchli hydrologickú cirkuláciu, takže sa predpokladá, že výskyt extrémnych udalostí bude frekventovanejší [2]. Záplavy môžu spôsobit' škody či už v krajine alebo l’udskými stratami. Napriek investíciám do protipovodňovej infraštruktúry (hrádze, priehrady), povodňové straty zostali v priebehov rokov vel'ké [3]. Obdobie sucha sa radí momentálne medzi závažnú problematiku, ked’že jeho výskyt a intenzita sa čoraz zvyšujú [4]. L’udstvo vníma sucho najmä z dôvodu nedostatku pitnej vody, narastajúcej hrozby požiarov, zvyšovaním teploty ohrozujúcej organizmy, degradáciou vodných ekosystémov apod. [5].

Očakáva sa, že globálne otepl'ovanie spôsobí rozsiahle zmeny zemského vodného cyklu, ktoré ovplyvnia dostupnost' vody pre mestá, pol’nohospodárstvo, splavnost' riek a výrobu energie [6]. Aby sa zmiernilo riziko vplyvu klimatickej zmeny, je potreba vytvorit' možnosti adaptácie a mitigácie medzi klimatickou zmenou a sektorov, na ktoré môže vplývat'. Pre vodu v krajine je možnost' prispôsobenia v rozlíšení využívania dažd'ovej vody, technike skladovania a ochrany vody, recyklovanie vody, efektivita zavlažovania a využívania vody [7]. Každé opatrenie môže mat’ popri pozitívnom dopade aj negatívny dopad na ekosystém, preto je nevyhnutné vyhodnotit' charakteristiky riečneho toku pred a po zmene režimu toku rieky [8].

Pomocou programu IHA sa v minulosti vo svete riešili nasledovné problematiky: hodnotenie prúdenia ekologického toku s ohl'adom na reakcie ekosystémov na hydrologické variácie v povorí rieky Honghui, Č́na [9]; výber minimálnych indikátorov hydrologických zmien pomocou analýzy hlavných komponentov rieky Gorai, Bangladéš [10]; optimalizácia prevádzky nádrže s ohl’adom na následky ekologických požiadaviek na množstvo a kolísanie vody na základe IHA parametrov [11].

Na Slovensku boli vykonané nasledovné analýzy zmien hydrologických režimov: identifikácia zmien režimu denných prietokov pre rieky Váh, Belá, Kysuca, Nitra, Hron, Topl'a, Ipel' a Krupinica [12]; vyhodnotenia trvania a frekvencie vysokých prietokov so zameraním na povodie rieky Dunaj [13]; vyhodnotenie zmien minimálnych denných prietokov vo vybraných staniciach na rieke Dunaj [14].

\section{METODIKA}

The Indicators of Hydrologic Alteration (IHA) je program na vykonanie štatistík, ktoré slúžia na posúdenie stupňa hydrologických zmien. Pozostáva zo 67 parametrov (33 IHA parametrov a 34 Environmental Flow Component EFC parametrov). Dané parametre boli vyvinuté na základe ich ekologického významu a ich schopnosti poukázat' aj na vplyv antropogénnej činnosti v režimoch prúdenia [15]. Svojou jednoduchost'ou, silnému teoretickému základu a zapojeniu biologicky relevantných hydrologických ukazovatel'ov si získal pozornost' hydrológov a environmentalistov na študovanie zmien režimov prirodzeného prúdenia, či zmeny hydrologických charakteristík po vplyve antropogénnej činnosti [8].

Program IHA pracuje s dennými hydrologickými radmi. Je vhodný na vyhodnotenie minimálnych aj maximálnych prietokov, dlhšie hydrologické rady sú potrebné $\mathrm{k}$ dosiahnutiu vyhodnocovania extrémnych udalostí, akými sú povodne či extrémne suchá, a ich dížka môže byt’ rozdielna v závislosti od variability klímy alebo závažnosti hydrologických zmien [12].

\section{Vstupné údaje}

V roku 2011 boli na území Slovenska spracované nové klimatické scenáre podl'a najnovších modelov GCMs a výstupov regionálych cirkulačných modelov RCMs. V práci boli použité dva klimatické scenáre: nemecký klimatický scenár MPI a holandský klimatický scenár KNMI. Dané klimatické scenáre predstavujú integráciou atmosférických a oceánskych dynamických rovníc. Ich okrajové podmienky sú výstupy globálneho modelu ECHAM5 a stredného emisného scenára SRES A1B, ktorý je stredne pesimistický scenár s globálnym oteplením o $2,9^{\circ} \mathrm{C}$ do roku $2100 \mathrm{v}$ porovnaní s rokom 1990. Modely a výstupy klimatických scenárov MPI a KNMI boli vytvorené na základe podrobnej analýzy dvadsiatich modelov (z nich bolo 15 RCMs a 5 GCMs) [16], [17], [18]. Výstupy scenárov sú dostupné od roku 1951 do roku 2100 a vzknikli kolektívom Katedry vodného hospodárstva krajiny Slovenskej technickej univerzity v Bratislave. Pri ich modelovaní sa použil modifikovaný zrážkovo-odtokový model HBV verzie TUW. Výstupmi klimatických modelov (zrážky a teploty vzduchu), boli k dispozícií downscalované do klimatických staníc jednotlivých povodí v dennom kroku do roku 2100 [19]. 
K dispozícií boli nasledovné typy dát (Tab 1.): pozorované dáta denných prietokov, ktoré nám poskytol Slovenský hydrometeorologický ústav; modelované dáta pomocou HBV modelu, simulované dáta klimatických scenárov MPI a KNMI pomocou HBV modelu.

Tab. 1 Rozdelenie použitých dát do jednotlivých časových periód.

\begin{tabular}{cc}
\hline Použité dáta & Časová perióda \\
\hline $\begin{array}{c}\text { Pozorované dáta (OBS), } \\
\text { MODEL HBV, MPI a KNMI dáta }\end{array}$ & $1.1 .1981-31.10 .2010$ \\
KNMI a MPI dáta & $1.11 .2010-31.10 .2040$ \\
& $1.11 .2040-31.10 .2070$ \\
\hline Vybranými vodomernými stanicami boli vodomerná stanica Liptovsḱ́ Mikuláš $(5550)$ v povodí rieky
\end{tabular}

Vybranými vodomernými stanicami boli vodomerná stanica Liptovský Mikuláš (5550) v povodí rieky Váh a vodomerná stanica Chmelnica (8320) v povodí rieky Poprad (Obr. 1). Analýzy sa v programe IHA vykonali parametrickou štatistikou pre časové rozhranie hydrologického roka.

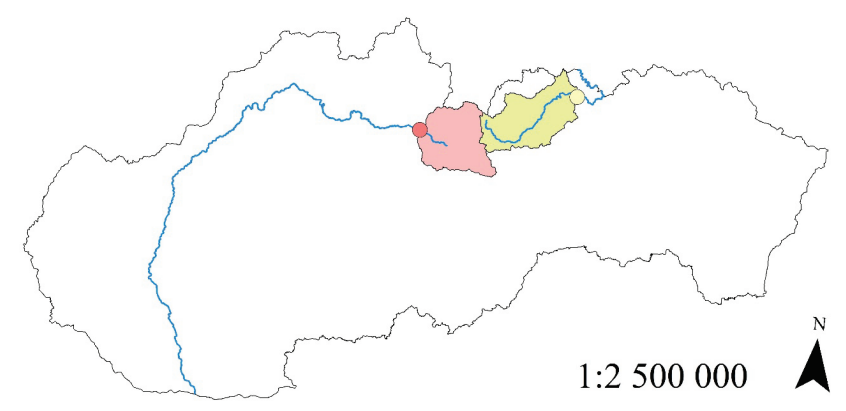

Vodomerná stanica Chmelnica (8320) v povodí rieky Poprad

Vodomerná stanica Liptovský Mikuláš (5550) v povodí rieky Váh

Obr. 1 Lokalizácia vybraných vodomerných staníc.

\section{VÝSLEDKY}

Vodomerná stanica Váh - Liptovský Mikuláš (5550) preukazuje v prvej skúmanej časovej perióde (1981-2010) najvyššie priemerné mesačné prietoky v mesiaci máj pri všetkých riešených dátach. Najmenšie priemerné mesačné prietoky sa vyskytujú v mesiaci február. Vzhl’adom na klimatické scenáre, dáta pre scenár MPI majú vyššie výsledné hodnoty priemerných mesačných prietokov v mesiaci máj, jún a október. Pre výsledne hodnoty priemerných mesačných prietokov podl'a klimatického scenára MPI je viditel’ný ich nárast v jesenných a zimných mesiacov do roku 2100 (Obr. 2). Naopak, na jar a v lete sa predpokladá pokles priemerných mesačných prietokov (najvyšší pokles priemerného mesačného prietoku v mesiaci máj).

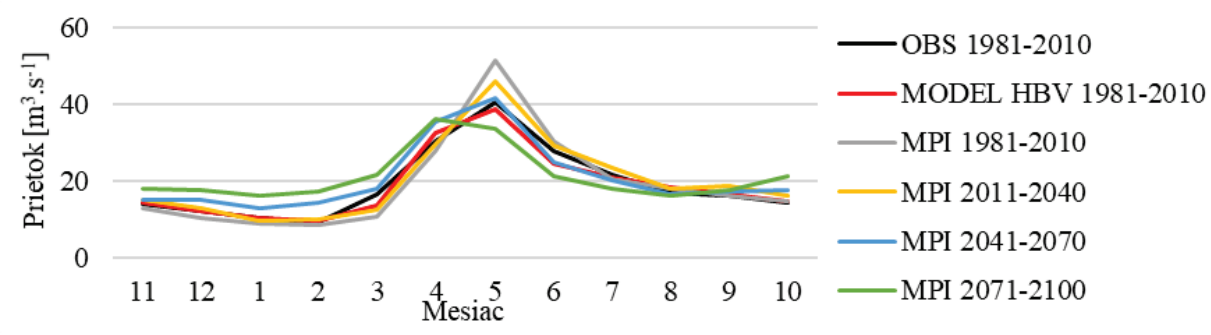

Obr. 2 Priebeh priemerných mesačných prietokov pre vodomernú stanicu Váh - Liptovský Mikuláš (5550) podl'a klimatického scenára MPI do roku 2100. 
Podl’a klimatického scenára KNMI (Obr. 3) platí podobný priebeh ako pri scenári MPI, kde sa predpokladá pokles priemerných mesačných prietokov do roku 2100. Hodnoty najvyšších priemerných mesačných prietokov podl’a oboch klimatických scenárov sa oproti minulosti s výskytom v majú, budú objavovat' v mesiaci apríl do roku 2100 .

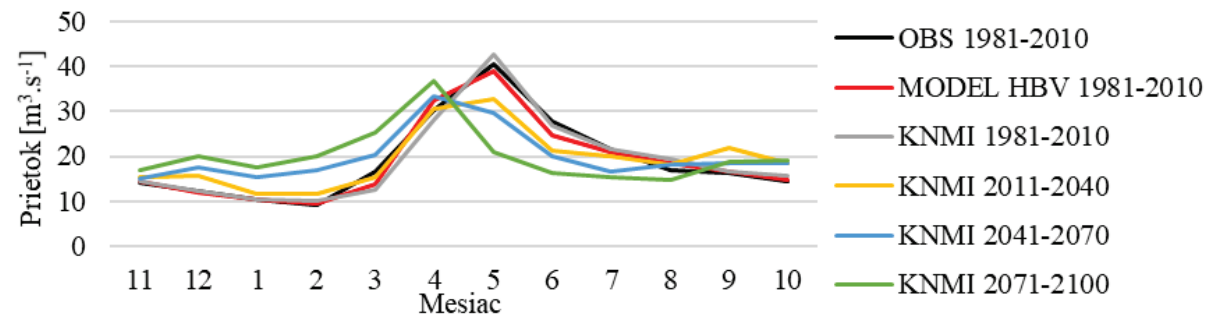

Obr. 3 Priebeh priemerných mesačných prietokov pre vodomernú stanicu Váh - Liptovský Mikuláš (5550) podl'a klimatického scenára KNMI do roku 2100.

Najvyššie priemerné mesačné prietoky pre pozorované dáta a dáta podl’a klimatického scenára vo vodomernej stanici Poprad - Chmelnica (8320) sa zaznamenali v mesiaci máj. Modelované dáta podl’a HBV modelu a simulované dáta klimatického scenára MPI evidujú najväčšie priemerné mesačné prietoky v mesiaci apríl. Najnižšie priemerné mesačné prietoky sa vo všetkých prípadoch skúmaných typoch dát vyskytujú v mesiaci január. Pre mesiace november, december, január, február a marec platí vyšší nárast v hodnotách priemerných mesačných prietokov podl'a oboch klimatických scenárov do roku 2100. Mesiace máj, jún, júl, august do roku 2100 predstavujú pokles $\mathrm{v}$ priemerných mesačných prietokoch pre dáta klimatických scenárov MPI a KNMI (Obr. 4 a Obr. 5).

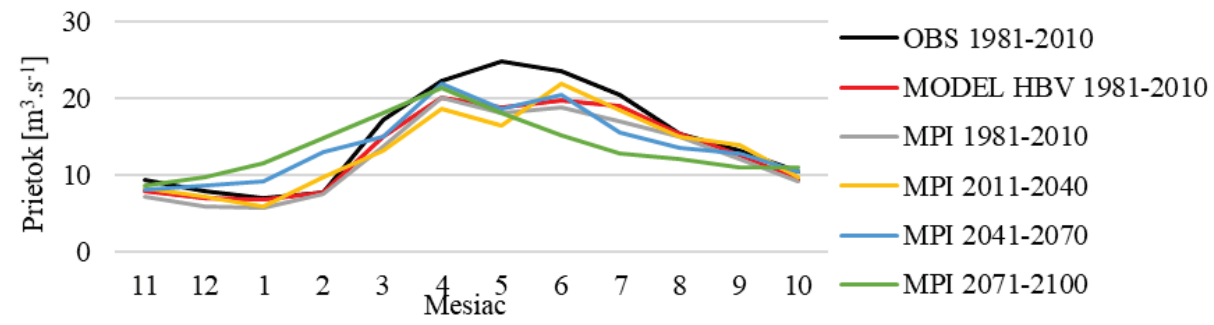

Obr. 4 Priebeh priemerných mesačných prietokov pre vodomernú stanicu Poprad - Chmelnica (8320) podl’a klimatického scenára MPI do roku 2100.

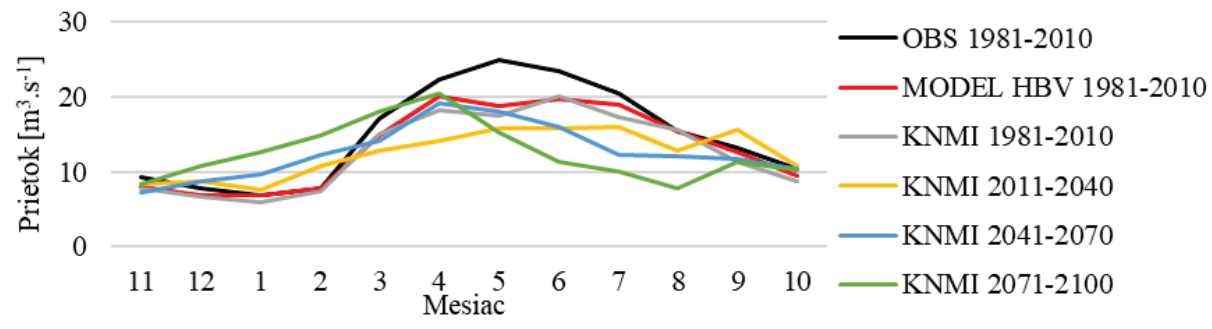

Obr. 5 Priebeh priemerných mesačných prietokov pre vodomernú stanicu Poprad - Chmelnica (8320) podl'a klimatického scenára KNMI do roku 2100. 


\section{DISKUSIA}

Mnohé modely všeobecnej cirkulácie (GCM) predpovedajú zvýšenie frekvencie a rozsahu extrémnych klimatických udalostí a premenlivosti zrážok, čo môže závažne ovplyvnit' zdroje povrchovej vody [19]. Pre Európu simulácie s globálnymi klimatickými modelmi predpovedajú nárast ročných zrážok na severe a ich pokles v Stredomorí. Pre strednú Európu sa predpokladá, že zrážok budú vyššie v zime a nižšie v lete [20]. Pramuk [21] vo svojej dizertačnej práci analyzoval priemerné mesačné prietoky vo vodomernej stanici Váh - Liptovský Mikuláš (5550) v časovom období 1931-2014. Svojou analýzou poukázal na pokles priemerných mesačných prietokov $\mathrm{v}$ mesiacoch apríl a november. Podl'a predkladaného príspevku do roku 2100 nastane $\mathrm{v}$ mesiacoch apríl a november nárast hodnôt priemerných mesačných prietokov podl'a oboch analyzovaných klimatických scenárov.

Najväčšia mesačná vodnost' sa do roku 2000 vyskytovala v apríli v povodiach Váhu a Popradu v mesiaci máj. Najmenšie priemerné mesačné prietoky sa v skúmaných povodiach do roku 2000 evidujú v mesiaci január [22]. Výsledky predloženej štúdie poukazujú na zmenu v priemerných mesačných prietokov v mesiaci apríl (nárast hodnoty priemerného mesačného prietoku z obdobia 1981-2010 do roku 2100 o 20\%) vo vodomernej stanici Váh - Liptovský Mikuláš (5550) podl’a modelovaných dát pre klimatické scenáre MPI a KNMI. Pre vodomernú stanicu Poprad - Chmelnica (8320) sa výskyt najvyšších priemerných mesačných prietokov presunie z mesiaca máj na mesiac apríl.

\section{ZÁVER}

Príspevok sa zaoberal analýzou zmien priemerných mesačných prietokov vo vodomernej stanici Váh Liptovský Mikuláš (5550) a Poprad - Chmelnica (8320). Výsledné hodnoty preukázali presun výskytu najvyšších priemerných mesačných prietokov z mesiaca máj na mesiac apríl do roku 2100. Táto skutočnost' predstavuje, že sa snehová pokrývka v severných skúmaných lokalitách na Slovensku neudrží dlho. Pokles priemerných mesačných prietokov v letných mesiacoch môže znamenat' zvýšený výskyt období sucha.

Už v súčasnosti je vidiet' prejavy klimatickej zmeny. V letných mesiacoch sa čoraz viac objavujú extrémne búrky a obdobia sucha. Zima sa prejavuje vyššími teplotami a čoraz menšou vrstvou snehovej pokrývky. Je dôležité študovat' nastávajúcu zmenu $\mathrm{v}$ hydrologickom režime vodných tokov, aby sa mohli $\mathrm{v}$ dostatočnom predstihu vybudovat' opatrenia, ktoré dokážu chránit' pred vodou, ale aj pomáhat' pri nedostatku vody.

\section{Pod'akovanie}

Táto práca bola podporovaná Agentúrou na podporu, výskum a vývoj na základe zmluvy č. APVV-200374 a projektom VEGA 1/0632/19.

\section{Použité zdroje}

[1] SCHNEIDER, C., C. L. R. LAIZÉ, M. C. ACREMAN a M. FLÖRKE. How will climate change modify river flow regimes in Europe? Hydrology and Earth System Sciences. 2013, 17, 325-339.

Dostupné z: doi:5194/hess-17-325-2013.

[2] KIM, B.-S., B.-K. KIM a H.-H. KWON. Assessment of the impact of climate change on the flow regime of the Han River basin using indicators of hydrologic alteration. Hydrological processes. 2011, 25, 691-704. Dostupné z: doi:10.1002/hyp.7856.

[3] KOZLOWSKI, T. T. Flooding and Plant Growth. Chapter 1 - Extent, Causes, and Impacts of Flooding. Pfysiological Ecology. 1984, 1-6. Dostupné z: doi.org/10.1016/B978-0-12-424120-6.50006-7.

[4] JANÁČOVÁ, T., L. LABUDOVÁ a M. LABUDA. Meteorologické sucho v oblastiach Slovenska s nížinným charakterom v rokoch 1981-2010. Geographia Cassovienis XII. 2018, 1, 53-64.

[5] FENDEKOVÁ,M., T. GAUSTER, L.LABUDOVÁ, D. VRÁBLIKOVÁ, Z. DANÁČOVÁ, M. FENDEK a P. PEKÁROVÁ. Analysing 21st century meteorological and hydrological drought events in Slovakia. Journal of Hydrology and Hydromechanics. 2018, 66, 4, 393-403. Dostupné z: doi:10.2478/johh-2018-0026.

[6] MINVILLE, M., F. BRISSETTE a R. LECONTE. Uncertainty of the impact of climate change on the hydrology of a nordic waterhed. Journal od Hydrology. 2008, 358, 70-83. Dostupné z: doi:10.1016/j.jhydrol.2008.05.033.

[7] NOVICKÝ, O., P. VYSKOČ, A. VIZINA, L. KAŠPÁREK a J. PICEK. Klimatická změna a vodní zdroje v povodí Vltavy. Výskumné ústav vodohospodářsky T. G. Masaryka. 2008, s. 30, ISBN 978-80- 
85900-79-8.

[8] ALI, R., A. KURIQI, S. ABUBAKER a O. KISI. Hydrologic Alteration at the Upper and Middle Part of the Yangtze River, China: Towards Sustainable Water Resource Management Under Increasing Water Exploitation. Sustainability. 2019, 11, 5176. Dostupné z: doi:10.3390/su11195176.

[9] TANG, Y., L. CHEN a Z. SHE. Evaluation of instream ecological flow with consideration of ecological responses to hydrological variations in the downstream Honghui River Basin, China. Ecological Indicators. 2021, 130, 108104. Dostupné z: doi.org/10.1016/j.ecolind.2021.108104.

[10] RAHMAN, M. A.T. M. T., S. HOQUE a A. H. M. SAADAT. Selection of minimum indicators of hydrologic alteration of the Gorai river, Bangladesh using principal component analysis. Sustainable Water Resources Management. 2017, 3, 13-23. Dostupné z: doi:10.1007/s40899-017-0079-6.

[11] YAN, M., G.-H. FANG, L.-H. DAI, Q.-F. TAN a X.-F. HUANG. Optimizing reservoir operation considering downstream ecological demands of water quantity and fluctuation based on IHA parameters. Journal of Hydrology. 2021, 600, 126647, s. 12. Dostupné z: doi.org/10.1016/j.jhydrol.2021.126647.

[12] PRAMUK, B., P. PEKÁROVÁ, P. ŠKODA, D. HALMOVÁ, V. B. MITKOVÁ. Identifikácia zmien režimu denných prietokov slovenských riek. Acta Hydrologica Slovaca. 2016, 17, 1, 65-77.

[13] PEKÁROVÁ, P., B. PRAMUK, D. HALMOVÁ, P. MIKLÁNEK, S. PROHASKA a J. PEKÁR. Identification of long-term high-flow regime changes in selected stations along the Danube River. Journal of Hydrology and Hydromechanics. 2016, 64, 4, 393-403. Dostupné z: doi:10.1515/johh2016-0045.

[14] HALMOVÁ, D, P. PEKÁROVÁ a I. MESZÁROŠ. Low flow change analysis in selected gauging stations on the Danube River. Acta Hydrologica Slovaca. 2011, 12, 2, 286-295.

[15] GAO, Y., R. M. VOGEL, CH. N. KROLL, N. L. POFF a J. D. OLDEN. Development of representative indicators of hydrologic alteration. Journal of Hydrology. 2009, 374, 136-147. Dostupné z: doi:10.1016/j.jhydrol.2009.06.009.

[16] LAPIN M., et al., 3. Scenáre klimatickej zmeny na Slovensku. In: MINĎAŚ, J., PÁLENÍK, . M.LAPIN a kol., NKP, 2011 76. MAJERČÁKOVÁ, O., ŠEDÍ., NEJEDLÍK, P. Dôsledky klimatickej zmeny a možné adaptačné opatrenia v jednotlivých sektoroch. Záverečná správa projektu. Zvolen: EFRA - Vedecká agentuúra pre ekológiu a lesníctvo, 2011, 25-32.

[17] MINĎAŠ, J., HOLÉCY, J., ŠKVARENINA, J. Modelovanie dopadu globálnych zmien klímy na neurčitosti vývoja biodiverzity a štruktúry ekosystémových služieb lesa. Životné prostredie. 2017, 51, 1, 14-20.

[18] SKONCOVÁ, D. Analýza zmien charakteristík prietokov na vybraných povodiach Slovenska. Diplomová práca. Bratislava. 2021,s. 76.

[19] VÝletA, R., HLAVČOVÁ, K., SZOLGAY, J., KOHNOVÁ, S., VALENT, P., DANÁČOVÁ, M., Kandera, M., ALEXIČ, M. Prehodnotenie štruktúry a metodiky kvantitatívna vodohospodárska bilancia povrchových vôd, 1. čast’. Vedecko-výskumná rozborová štúdia. Bratislava, 2020, s. 282.

[20] CHEN, J., F. P. BRISSETTE a R. LECONTE. Uncertainty of downscaling method in quantifying the impact of climate change on hydrology. Journal of Hydrology. 2011, 401, 190-202. Dostupné z: doi:10.1016/j.jhydrol.2011.02.020.

[21] DANKERS, R. a L. FEYEN. Climate change impact on flood hazard in Europe: An assessment based on high-resolution climate simulations. Journal of Geophysical Research. 2008, 113, D19105, s. 17. Dostupné z: doi:10.1029/2007JD009719.

[22] PRAMUK, B. Idenfitikácia zmien hydrologického režimu riek v povodí Dunaja. Dizertačná práca. 2016, s. 130.

[23] POÓROVÁ, J., P. ŠKODA, Z. DANÁČOVÁ a V. ŠIMOR. Vývoj hydrologického režimu slovenských riek. Životné prostredie. 2013, 47, 3, 144-147. 